\title{
POPULAR JUSTICE IN ZINACANTAN ${ }^{1}$
}

\author{
By Jane Collier
}

\section{Introduction:}

In recent years there has been a growing, world-wide, interest in systems of "popular justice"; in tribunals that are easily accessible to the ordinary man, where justice is quick and cheap, where procedures are simple and intelligible so that lawyers are unnecessary. Such tribunals are said to have several advantages over more formal courts which, constrained to apply universal norms impartially and staffed by legal professionals, are overcrowded, expensive and alienating. It is argued that popular tribunals which are designed to involve the ordinary man in the process of justice should lead to greater litigant satisfaction, should increase public committment to the political system which provides such cheap and intelligible justice, and should eventually lower the crime rate as ordinary citizens develop a sense of responsibility for the maintainance of social order. Such ideals may be illusory or far from realization, but interest in them has sparked several experiments in popular justice and has led to renewed interest in studying functioning popular tribunals. Zinacantan, a Maya community in the highlands of Chiapas, Mexico, has what might be classified as a popular tribunal: a local "court" that is easily accessible, where hearings are held without delay, in the native language, and where most disputes end with a formal reconciliation between the parties. In this paper, I will describe the ideology and the political organization that underlies the operation of the Zinacanteco town hall court in an attempt to formulate more general propositions about the practical requirements for realizing social ideals through legal reform.

A brief survey of the popular tribunals that have been created reveals that many of them have failed to achieve popularity. The courts may be accessible, quick and cheap, but still avoided by ordinary citizens who prefer to solve their problems through other means. The Zinacanteco town hall court, however, is very popular. It is not only patronized by citizens from the entire township, but gossip networks spread reports of its decisions. The Zinacanteco court appears to have the kind of impact on public opinion that is desired, but not always realized, by the creators of popular tribunals.

In this paper I propose to examine the two factors that I consider most important in accounting for the popularity of the Zinacanteco town hall court: the ideology behind court procedures which stresses the intrinsic social worth of each individual,

\footnotetext{
1 This paper is the response to a question posed by a colleague at the Stanford Law School, who, after reading my book on the legal system of Zinacantan (Collier 1973), said, in effect, "So What?" He later added, "Mere descriptions of exotic legal systems tell us nothing. Anthropologists should use the insights they gain from their studies to help lawyers solve real problems: such as how to design popular courts that will fill the needs of ordinary people and promote their involvement in the process of justice."

The research on which this paper is based was carried out between 1960 and 1970 and was supported by grants from the National Institute of Mental Health (Grant No. 02100 and Predoctoral Research Fellowship 1-Fi-MH-35,444) and by a National Science Foundation Postdoctoral Fellowship.

I owe a debt of gratitude to Professor Evon Z. Vogt, director of the Harvard Chiapas Project; to the many other Project members whose suggestions and criticisms directed my thinking; and to all of the citizens of Chiapas, both Zinacanteco and Ladino, who offered me their hospitality and who graciouly answered my of ten naive questions.
} 
thus requiring the reintegration of wrongdoers, and the political system which rewards the powerful for heeding the wishes of the powerless. It is my assumption that courts will be most popular when they fill the needs that citizens themselves perceive, and that citizen needs are best filled by a court where power differentials are minimized and where individuals are encouraged to express their wishes freely. Although the Zinacanteco court can be examined to provide a model for designing popular tribunals, I think it is also important to consider the future of the Zinacanteco court itself. As social and economic changes overtake Zinacantan, the two bases of the town hall court's popularity appear to be threatened. Western ideology which stresses individual responsibility over individual worth may weaken the Zinacanteco concern for reintegration, while political changes threaten to create a situation in which leaders may find it more rewarding to banish wrongdoers than to seek their consent and support.

\section{Some Examples of Popular Tribunals:}

Before describing some of the recent attempts to create alternatives to formal courts it is necessary to develop a working definition of a "popular tribunal". There is general agreement that such tribunals are agencies designed to settle disputes which are (1) recognized by the State, (2) easily accessible in terms of convenient location and low fee requirements, and (3) intelligible; with hearings conducted in the local language, using simple procedures that are comprehensible to an ordinary man without the aid of a lawyer. Some writers would include two other criteria: (1) that such tribunals be staffed by non-professionals and (2) that they attempt explicit political education. These criteria have been stressed by planners in socialist countries who seek to educate citizens and to involve them in political processes.

Small Claims Courts in the United States were created to allow ordinary citizens easy access to rapid and cheap justice. They were not designed to promote social change, but simply to overcome the conditions of overcrowding, delay and excessive professionalization that prevailed in the existing lower courts. The failures of small claims courts are common knowledge. Although a few courts are used by ordinary citizens, most of them are patronized by businesses, landlords and collection agencies. Instead of attracting the ordinary citizen with a small claim, they have provided a cheap forum for businessmen seeking to collect debts.

The popular tribunals of Soviet Russia, Poland and Cuba were all created under the impetus of a "new" ideology and were designed to aid in the development of a "new" society. Because social planners wanted to involve all citizens directly in the administration of justice, they used local laymen as judges, designed penalties that were rehabilitative rather than punitive, and urged that decisions be accompanied by sermons to teach the public the new laws and to involve them in the detection and prevention of anti-social conduct (Tiruchelvam n.d.). Critiques of socialist popular justice stress a common problem area. There is a tendency for tribunals either to become too popular - too closely identified with local interests so that national goals suffer - or to lose their popular character as national goals are stressed at the expense of local beliefs and customs. 
Popular courts in the former British colonies of Tanzania, India and Burma were all instituted by governments which sought to forge a "new" society from the best elements of indigenous custom and modern socialism. But the new popular tribunals, which must compete with existing indigenous institutions, face more serious problems than the popular courts of other socialist countries (Tiruchelvam n.d.). Given that ethnic and regional loyalties tend to be quite strong relative to national identity in such former colonies, popular courts that become too popular may foster separatist tendencies, while courts that are unpopular promote the rise of alternate dispute settling agencies that may become the foci of anti-nationalist sentiment.

Almost all of the recently created popular tribunals are courts on the lowest level of a judicial hierarchy. They are designed to replace or supplement lower level courts, leaving the upper level courts intact and firmly in the hands of a professional judiciary. All of them were created in response to the felt need to involve ordinary citizens in the process of justice, to make justice more available to them, and to involve them in the task of maintaining social order. At least three forces in the modern world contributed to these felt needs: (1) modern political ideology that requires government to "serve the people", (2) the need to organize the citizenry for successful implementation of social and economic development goals, and (3) the rising crime rates that appear to accompany urbanization and industrialization.

But public participation is difficult to maintain. Small claims courts in the United States failed to attract the ordinary citizen, and socialist courts that have advocated national goals over local ideas of justice have similarly alienated the people they were designed to attract. "Popular" tribunals that lose their popularity necessarily fail to achieve the larger goals set by public planners. At best, such courts merely fail to move the people. At worst, they promote feelings of alienation that undermine support for the government.

Although there is a danger that popular tribunals which become too popular might succumb to regional interests, long term national goals are probably better served by preserving the popular character of tribunals rather than by allowing the public to become alienated from the legal system. Populations which find all litigation too costly or populations which have developed alternative remedy agents are very hard for national planners to reach, while tribunals that retain popular patronage and support provide government agents with direct access to the people.

\section{The System of Popular Justice in Zinacantan:}

The local "court" at the town hall in the ceremonial center of Zinacantan has several of the characteristics of a "popular tribunal". It is recognized by the State; relatively accessible in terms of location, particularly since the growth of truck travel; and it is cheap to approach. Hearings are conducted in Tzotzil, the native language, and the court follows common sense procedures that are understood by the ordinary citizens of the township. Justice is quick. Hearings, once begun, rarely last longer than a day. And most Zinacantecos seem to believe that the settlements are fair. The majority of cases end with the party found to have 
committed the greatest wrong begging pardon of the offended party and promising to repair the damage or to behave better in the future.

But the town hall court in Zinacantan, while recognized by the State, has succumbed to local interests. Although it was created on a Spanish rather than indigenous model, land is regularly reformed to comply with changes in the state laws dictating township organization, the court upholds local custom instead of the civil and penal laws of the state. Court settlements are closer to the solutions proposed by local Zinacanteco elders than to those of higher state courts. Unlike the situation in former British colonies where newly instituted popular tribunals must compete with indigenous institutions, the long-established town hall court of Zinacantan has become part of the "indigenous" system. It forms the highest level of appeal for customary law.

Legal Levels in Zinacantan: Zinacantan is a community of approximately 12,000 Indians who wear a distinctive costume and live in small houses scattered over the forested mountains and valleys of their township. Residence tends to be patrilocal. Sons try to settle near their fathers, giving rise to local descent groups composed of the clustered houses of relatives. Elders of particularly large and cohesive units tend to become local level political leaders who often act as mediators in settling disputes that arise between kinsmen and neighbors. To hear a case, the elder usually invites the disputants and their supporters to gather in his house where he will listen to both sides and suggest possible solutions. He has no formal power to impose a settlement on unwilling disputants, but his words carry weight and his proposed solution is usually upheld by the town hall court if the case is appealed.

Zinacantan is divided into halmets (parajes), each composed of several local descent groups. Hamlet members tend to know one another quite well. Most marriages occur between hamlet members and hamlet children grow up together. When a dispute arises between members of the same hamlet, the disputants have a choice of means for seeking a settlement. The simplest course is for the person who committed the wrong to present a bottle of the local rum to the offended person and beg his pardon. If the offended person accepts the rum, a solution can be worked out without invoking a third party. But if begging pardon should fail, or if both sides claim to be in the right, a respected hamlet elder may be asked to hear the case. Or, one side may choose to go directly to the town hall court in the ceremonial center.

The ceremonial center of Zinacantan is a typical Maya vacant town. It contains two Catholic churches, the town hall (cabildo), a few stores and the scattered houses of men temporarily holding civil or religious office. The town hall is a long, low building with a covered porch running the length of the front where the court meets. The elected civil officials of Zinacantan spend their days seated on the benches that line the inner wall of the porch, ready to hear and resolve any disputes that are brought before them. There are twelve civil officials but only a few of them are on duty at any one time. Although there are four jueces, most of the cases are settled by the Presidente, the highest civil official. Any Zinacanteco or outsider can ask the civil officials to hear a dispute, but most the the cases that reach the court are between Zinacantecos who belong to different hamlets, or between persons from the same hamlet who have failed to obtain a satisfactory solution by less formal means. 
Beyond the borders of Zinacantan lie the more formal legal agencies of the state and national governments that are run by Ladinos. Although a mono-lingual Zinacanteco can approach these agencies in search of justice, the failure to speak Spanish is a true handicap. Zinacantecos also feel hesitant about approaching outside agencies because fellow Indians believe that only selfish persons who are after personal gain or seeking to destroy an enemy will bypass local justice. At the same time, local mythology stresses the high cost of appealing outside the community. Ladinos are pictured as money-hungry; eager to take a Zinacanteco's hard earned cash and unlikely to produce desired results. In fact, the mythology implies that a Zinacanteco who lodges a complaint against someone else is as likely as his enemy to end up in jail.

Common Types of Disputes: Most of the cases that reach the town hall court involve people linked in long-term relationships. There are few disputes between strangers in Zinacantan. Outsiders rarely have cause to enter the township, and the truly deviant Zinacantecos who might attack strangers tend to leave the community. Most Zinacantecos spend their lives in the hamlet where they were born, living beside relatives and neighbors known since childhood. Disputes that arise among persons in such enduring, face to face relationships are necessarily complex affairs of wrongs committed and duties ommitted over a long period of time. Although Zinacantecos commit the standard range of crimes found all over the world, most disputes center on less dramatic actions and are resolved with an eye to the future relationship between the parties. For this reason, it is best to base a typology of disputes on the kinds of relationships between persons, rather than on the nature of the wrongful act that caused a latent dispute to erupt into open conflict.

Relations between blood kinsmen are necessarily strained in a society where a man's status is linked to land ownership and where land is usually acquired through inheritance. But the prevailing ideology stresses cooperation between kinsmen while the practical requirements of economic and political life force kinsmen to be dependent on one another. Whenever a dispute erupts between kinsmen, there is less attempt to allot blame than to patch up the quarrel by redistributing property or by reaffirming existing rights.

Marital disputes are the most frequent cause of legal action in Zinacantan. Wives come as strangers to live with their husbands' families where they are not only unhappy at having left their natal homes, but, as outsiders, are blamed for provoking quarrels between kinsmen. Zinacanteco ideology gives a husband complete authority over his wife, but few practical means of enforcing his rule. Wife beating is a common occurrence. Beaten wives regularly leave their husbands and appeal to kinsmen or township officials for aid. Most quarrels end in reconciliation, but often a young wife will only return on the condition that she and her husband build a separate house.

Courtship in Zinacantan is a long and expensive affair, of ten lasting two years and costing the boy's family several hundred pesos. Such a brideprice is justified by the belief that a girl's family must be repaid for the expenses they incurred in raising a daughter who will leave them as soon as she is able to do useful work. Payments are usually made in foodstuffs which must be consumed as soon as they are received by the girl's family. As time passes, the girl's family thus becomes more indebted to the boy, and courtships become harder to break because 
Zinacantecos believe that a boy who will not receive his bride should be repaid so that he can court another girl. Broken courtships, elopements, and flirting with an unmarried girl are all serious affairs which involve large sums of money and are therefore often taken to the town hall court or to the Ladino officials in San Cristobal before a settlement can be reached.

Zinacanteco neighbors who are not linked by kinship or affinal ties may quarrel over a variety of issues, from inpaid debts and broken agreements, to trespassing animals, drunken fights and malicious gossip. Such quarrels tend to be more straightforward than the complex disputes of kinsmen or spouses and can of ten be resolved by cash payments which end obligations.

Although outsiders may regard Zinacantecos as a violent people who murder each other over fears of witchcraft or who injure each other in drunken brawls, reality is more complicated. Witchcraft beliefs play an important role in Zinacanteco quarrels, but the culture provides several ways for someone who feels victimized to protect or revenge himself without having to resort to murder. It is true, however, that Zinacantecos tend to explain all the murders that do occur by saying that the murderer probably believed his victim to be a witch. It is also true that Zinacanteco men drink a great deal and occasionally become violent. But once again it is not clear whether violence can be directly attributed to Zinacanteco drinking patterns, for the only culturally valid excuse for resorting to violence is that the aggressor was too drunk to know what he was doing. Zinacantecos who have committed violent acts go to great lengths to prove to their fellows that they had been drinking heavily at the time. Whenever a case involving violence or witchcraft is heard by an elder or at the town hall court, there is less emphasis placed on punishing the offender than on assuring the future welfare of the victim: seing that he is protected from future harm and compensated for his injuries.

Zinacanteco Ideology: Native cosmology - the set of beliefs about the nature of social and cosmic order, about spiritual relations between men and about relations between men and supernatural beings - gives each Zinacanteco, however lowly or insignificant, an important role to play. Unlike Western ideology which puts social welfare above individual needs or desires, Zinacanteco ideology puts individual desires first. Unless individuals are satisfied, social order will break down. The relationship between ideology and behavior is very complex. There is no simple way to predict behavior from a knowledge of a belief system. But to the degree that ideology determines the overt function of a court, it affects the roles assigned to all participants and the procedures followed in seeking a settlement. In the political ideology that underlies the legal systems of common law, civil law and socialist countries, social order is believed to rest on individual adherence to rules. Courts, in such countries are designed to affect overt behavior, to ensure that people fulfill their legal obligations and do not commit wrongful acts. Zinacanteco hearings, on the other hand, are designed to placate individuals, to change men's hearts. Zinacanteco ideology thus provides important protection for the powerless. As only the individual can know what is in his heart, Zinacanteco elders and judges cannot dictate solutions. They must, in theory, obtain the overt and freely given consent of both parties to a dispute if social order is to be restored. 
Zinacantecos believe that the most significant interaction between individuals takes place on a spiritual level between their souls, instead of on the physical level between their bodies (Vogt 1969). Every Zinacanteco has two types of soul: an inner invisible one and an animal spirit companion. All people are not created equal, for some are born with strong souls and powerful spirit companions while others are born with weak souls and insignificant animals. As time passes, those with strong souls flourish and become leaders, while those with weak souls either die young or survive by seeking protection from a spiritually powerful patron. But the strong are not invulnerable, nor are the weak helpless. The gods, who have the most power, will punish even strong persons who behave improperly while they will protect the weak who are innocent. The supernatural world is not entirely predictable, however, because witches, through deceitful prayers, may trick the gods into punishing the innocent. These beliefs provide a rich and flexible conceptual framework within which the ordinary Zinacanteco can explain his fate. His own misfortunes can be blamed on the maliciousness of witches, while the misfortunes that befall his enemies can be credited to the justice of the gods.

These beliefs about spiritual interaction underlie Zinacanteco legal procedures. When one person wrongs another, the victim of the wrong is believed to carry anger in his heart that cries out to the gods for vengeance. If a victim's anger is not placated, the gods will answer his repeated pleas and cause the offender, or some member of his family, to sicken and die. This belief explains the emphasis on future relations that pervades Zinacanteco hearings. The aim of a settlement procedure is to find a solution that removes the threat of supernaturally caused illness by placating the victim's anger without arousing anger in the heart of the offender.

The belief in supernatural vengeance prescribes appropriate attitudes for all participants in a hearing. A person who has been wronged is expected to take his case to an elder or to the town hall court and to be moderate in his demands for compensation. Hesitation in bringing up a case or adamant refusal to accept compensation is taken as an indication that the complainant wants the offender to sicken and die. People who "do not know how to forgive" are open to charges of witchcraft, particularly if the wrongdoer falls ill. But wrongdoers are also expected to seek a forum for placating their victims. If an offender refuses to beg pardon or offer compensation, he risks illness for himself or some member of his family. This is not an idle fear in a community where serious illness is endemic and where infant mortality rates are very high.

These beliefs also prescribe a conciliatory role for the third party. He must be a mediator who seeks a compromise acceptable to all. He cannot act like a judge who listens to the facts of the case and then makes a decision based on socially accepted rules. A Zinacanteco mediator cannot impose his own solution on unwilling disputants, however powerful he is or however just he believes his solution to be. He must obtain the overt and freely given consent of both disputants if he is to avoid punishment from the more powerful gods who will respond the to the pleas of a disputant who seeks vengeance for having been forced to accept a solution he felt was unjust.

The procedures followed during a Zinacanteco hearing reflect these ideological constraints. At the beginning of a hearing the complainant is asked to state the outcome he desires; to declare the conditions that will calm the anger in his heart. He may back up his claims by giving his version of the facts of the case, but there 
is no belief that the facts dictate the outcome. Then the offender is allowed to state the settlement he would prefer and to recite his version of the facts. Although most of the hearing is taken up with a discussion of the facts, there is little effort made to establish guilt or to offer proof of wrongdoing. The aim of the hearing is to reach a compromise outcome that will satisfy both sides, and discussions of the "facts" are punctuated with discussions of possible outcomes. A Zinacanteco hearing usually continues until both sides indicate overt agreement with a proposed settlement, and it ends with everyone drinking rum to signify reconciliation.

Zinacanteco Political Organization: Although Zinacanteco ideology makes it difficult for the powerful to publicly justify disregarding the wishes of the powerless, it would be wrong to assume that ideology alone protects the weak from the strong. Zinacanteco leaders have been known to force unwilling disputants to express consent for a solution they did not desire. In order to gain a clearer understanding of how Zinacanteco popular justice actually works, it is necessary to examine the political organization of the community: to examine the practical as well as the ideological checks on the abuse of power. In practical terms, powerful men in Zinacantan find it hard to ignore the wishes of the powerless because, generally speaking, leaders are more dependant on followers than followers are on leaders.

Zinacantan resembles what Wolf has described as the "closed, corporate" type of peasant community (1955). Membership is restricted, only community members may own land, cultural barriers restrict the entry of outside goods and ideas, and the system of religious offices serves to convert differences in wealth into differences in prestige. Economic differences within the community are minimized. There is no leisure class. Everyone works and the division of labor is very simple. Almost all men are corn-farmers; almost all women perform the domestic chores of housekeeping, cooking and weaving clothes. All children are taught the skills they will need in adult life, tools are simple and cheap to acquire, and land, while not a free good, is relatively accesible to all because most Zinacanteco corn is grown on lowland fields rented from Ladinos. The economic system within the community is thus too simple to allow some people to gain power over others through the control of crucial resources. And because no one can effectively control another's life chances, political followings cannot be based on coercion but must the built on consent. Followers must be convinced that a leader holds legitimate authority or they must be rewarded for their obedience.

Despite the egalitarian economic system, Zinacantecos are not all equal in wealth, prestige or power. Some men acquire a lot of land, other are landless; some attain great prestige, others are despised; and some men are able to obtain power over others: able to have their commands obeyed despite resistance and to make decisions that affect many lives. For the sake of brevity, I will discuss only two common types of career pattern: that of the ordinary man who aspires to respected elderhood and prestige within his hamlet, and that of the man who seeks to become a community leader.

The normative system of Zinacantan gives older men authority over juniors and the economic system reinforces the normative pattern by ensuring that elders have more direct access to labor and capital than younger men. A young man begins his adult life in debt. His elders assure him that he must repay his father for having reared him, in order to marry he must borrow money from his father to pay the 
brideprice, and if he hopes to inherit a portion of his father's land he must play the part of a loyal and respectful son. Simply by growing older, a man tends to become a creditor instead of a debtor. His father dies, he inherits land in his own right, and his children grow old enough to become valuable laborers and debtors in turn. Able to run a more efficient farming operation with "free" family labor, a man begins to acquire substantial wealth which can be converted into prestige and power over others by being used to sponsor religious ceremonies or by being lent to kinsmen and neighbors in need. An older man still farms corn, but he is able to leave a substantial portion of the hard labor to his sons while he engages in the more pleasurable and prestige-giving activities of conducting rituals and conferring with other elders. Although the normative and economic system combine to convince a young man that he is dependant on the goodwill of his father, in actuality, it is the older man who is deeply dependant on his children. While a young man may farm other fields and find other brides, an older man cannot find such loyalty and labor at so cheap a price. When a conflict arises between seniors and juniors or between creditors and debtors, therefore, elders prefer to have the wrongdoer acknowledge his faults and willingly promise to behave better in the future. Punishment serves little purpose: a junior who is jailed or banished is useless, and coercion is impractical because a junior who is forced to accept a settlement will probably ignore the terms of the agreement once he has left the town hall court. Given the fact that most conflicts occur between people involved in long term relationships, it is easy to see why most plaintiffs prefer reconciliation to vengeance and why such effort is expended to obtain the willing consent of the offender.

Community political leaders are similarly dependent on their followers. Men who seek the power to make decisions that affect community welfare must obtain, and keep, a large body of loyal supporters. Such followings have traditionally grown around leaders capable providing benefits - preferably land - for the Indian community. The most powerful leaders of the 1940's and '50's were the men who obtained land under the Mexican land reform program, and several contemporary leaders are engaged in efforts to buy ranches or to obtain additional land grants from the government. A young man who aspires to obtain such benefits must demonstrate two types of expertise: he must be able to deal effectively with Ladino officials and he must be able to settle quarrels among his followers without alienating either disputant. The need for the first skill is obvious, but why should leaders be effective dispute settlers? The answer lies in the way benefits are extracted from the national government. To be successful, a leader needs a large body of followers to sign petitions and to provide the cash needed for trips to Mexico City, legal fees and bribes. The leader who alienates a disputant not only looses one follower, but may lose some of his other supporters who come to doubt his ability to maintain a sufficient following for successful dealings with the national government. Important political leaders, like respected elders, have a vested interest in promoting conciliatory settlements: in obtaining the willing consent of both parties in a dispute. 


\section{Conclusion:}

In this paper I have explored what I consider to be the bases of the popularity of the Zinacanteco town hall court: the ideology that stresses the social worth of each individual, and the political system which rewards the powerful for heeding the wishes of the powerless. As a result, power differentials in the court are minimized and all disputants are encouraged to express their views of a desireable settlement.

Although Zinacanteco ideology and political organization cannot be directly transplanted into other cultures or other social settings, I feel that creators of popular tribunals may learn from the Zinacanteco example. It seems to me particularly important to allow disputants to play an active role in determining the provisions of a settlement. All too of ten disputants are confined to discussing the "facts". If they wish to influence the outcome, they must do so through selective presentation of the evidence. This procedure has the effect of discriminating against inexperienced individuals or members of cultural minorities who do not know the accepted relationships between facts and outcomes. Allowing disputants to speak for themselves would not only increase disputant committment to the procedings, but would allow national agents who seek to educate the public important insights into what members of that public think is important. As any sound program of education must be tailored to the students' needs and experience, so tribunals may become truly educative when court officials can begin from a sound knowledge of the felt needs and desires of disputants.

As programs for economic and social development bring changes to Zinacantan, I think it will be important to preserve the popularity of the town hall court. Although serious crimes and important civil cases will probably be referred to higher courts in the future, I believe it is important to preserve a tribunal where the petty quarrels and minor crimes of everyday life can be handled rapidly, cheaply, and in a manner that promotes reconciliation and reintegration. As Western ideology, with its stress on individual responsibility, threatens to undermine the Zinacanteco concern for the social worth of each person, and as economic changes threaten to create a situation where owners of valued resources will have such control over the life-chances of others that leaders will feel free to use coercion rather than persuasion, new means must be developed to preserve the town hall court as a popular tribunal where power differentials are minimized and where each person is made to feel important.

\section{References:}

Collier, Jane

1966 "El noviazgo Zinacanteco como transaccion economica" in Los Zinacantecos, E. Z. Vogt, editor. Coleccion de antropologia social, 7. Mexico, D. F., Instituto Nacional Indigenista. 1968 "Courtship and Marriage in Zinacantan, Chiapas, Mexico" Middle American Research Institute

1973 Law and Social Change in Zinacantan. Stanford. Stanford University Press. Tiruchelvam, Neelan

n.d. "The Ideology of Popular Justice" Yale Law School Program in Law and Modernization, paper No. 21. Unpublished Mimeo.

Vogt, Evon Z.

1969 Zinacantan: A Maya Community in the Highlands of Chiapas. Cambridge, Mass. Harvard University Press. Wolf, Eric

1955 “Types of Latin American Peasantry: A preliminary Discussion" American Anthropologist 57: $452-71$. 
thus the prestige of the federal constitution was diminished: The incessant amending of the constitution (more than 200 modifications since 1917) prevented the Supreme Court from interpreting the basic constitutional provisions in an evolutionary way. This point of view underlines the necessity of more, and even of multidisciplinary studies in analysing the country's judicial system both on the national and the local level. Only this way shall lead to fundamental and not only circumstantial propositions striving for a judicial reform, a reform that has been overdue since a long time.

\section{Anthropology and Sociology of Private Law in Mexico}

\section{By Volkmar Gessner}

In view of the recent discussion about the scientific value of "law and development"-studies it appears to be useful to describe the present state of knowledge concerning specific geographical regions and specific areas of law and so to allow a critical review and possibly a reorientation. What we have certainly learned is that approaches which look merely for better legal social engineering in developing countries are subject to serious doubt.

This paper is intended to give access to empirical studies on the relationship between private law (including labour law) and society in Mexico. By describing concrete phenomena of the Mexican law in action (II and III) and introducing subsequently (IV) theoretical concepts for structuring the presented factual knowledge the author argues in favor of a theoretical perception of the function of law in the third world. This position is in sharp contrast to other (legal) scholars participating in the "law and development"-discussion who defend that the only answer to dogmatic orientations of the traditional legal sciences in developing countries is not a social science but a policy approach. The studies referred to in this article are non-normative altogether. Proposals for legal reform are completely absent and even the topics themselves were far away from the mainstreams of political discussions by the time when the research was done in the country. As a result this research had no impact on the making of new laws. On the other hand it is of great importance for legal sociology that Mexico is now one of the few regions in the world where it is possible to analyse the whole range of social structures under the perspective if and to what degree social behavior is influenced by law.

\section{Popular Justice in Zincantan}

\section{By Jane F. Collier}

The town hall court in the Tzotzil Maya community of Zincantan, Chiapas, Mexico functions as a highly successful popular tribunal. It is easily accessible to all citizens, justice is quick and cheap, and it uses procedures intelligible to the uneducated layman. At the same time, the court is highly popular and news of its activities spread rapidly through the community. As a result, it not only 
serves to "settle" most of the disputes that arise among kinsmen and neighbors, but it also serves to educate citizens about current community standards. This paper describes the two features which appear to be most important in accounting for the popularity of the town hall court: (1) the ideology behind court procedures which stresses the intrinsic worth of each individual, thus requiring the reintegration of wrongdoers, and (2) the political system which rewards the powerful for heeding the wishes of the powerless.

\section{Overwhelming neighborhood: Mexico's relations with the United States}

\section{By Wolf GrabendorfF}

The neighborhood between the USA, a world power, and Mexico, a poor country, is of a special kind, since it has very little in common with the type of neighborhood the USA shares with Canada at its northern frontier. In contrast, the USA borders the Third World at its southern frontier. The Rio Grande is much more a cultural threshold than an ordinary border. The problems and conflicts which arise from this type of neighborhood, therefore, are much less "neighborhood" problems than "gap" problems. They are especially difficult to solve when the "neighborhood" problems also become "gap" problems. Therefore, a special type of relationship has developed throughout history between Mexico and the USA, whereby Mexico was forced to develop specific methods and instruments in order to face its overwhelming neighbor.

This paper deals with the three different types of conflicts which exist between these two structurally so very different countries. It shows that the specific "neighborhood" problems such as drug smuggling, fishing rights, and border regulations are probably the easiest to solve. Greater difficulties arise from the mixture of "neighborhood" and "gap" problems which account by far for the largest group. Among them are tourism, trade, border industries, illegal immigration, foreign investments, and the general implications of the Mexican development model. In all of these areas, the USA profits a great deal from Mexican dependency, and it is easily demonstrated that this type of bilateral conflict is much deeper rooted than it appears to be. The final and smallest conflict group consists of specific "gap" problems such as credits and Third Worldism as a foreign policy posture.

To cope with all these bilateral problems with the USA, the Mexicans have developed a double strategy: A more defensive legalistic approach on the one hand and the use of bargaining power through cooperation with the Third World on the other. The lack of countervailing power impels Mexico to seek general principles in international affairs where its national interests can be sustained more forcefully against the "colossus of the north". 